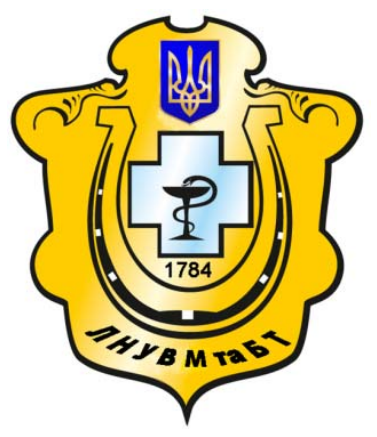

Науковий вісник Львівського національного університету ветеринарної медицини та біотехнологій імені С.3. Гжицького

Scientific Messenger of Lviv National University of Veterinary Medicine and Biotechnologies named after S.Z. Gzhytskyj

doi:10.15421/nvlvet6631

ISSN 2413-5550 print

ISSN 2518-1327 online

$\underline{\text { http://nvlvet.com.ua/ }}$

УДК 636.085.3:619:616.992.28

\title{
Діагностика та заходи боротьби з пастерельозом гусей в приватному зоо- парку Полтавської області
}

\author{
О.О. Передера, І.В. Лавріненко, І.А. Жерносік \\ ua151@ukr.net \\ Полтавська державна аграрна академія \\ вул. Сковороди, 1/3, м. Полтава, 36003, Украӥна
}

\begin{abstract}
У статті наведені результати дослідження спалаху пастерельозу гусей в приватному зоопарку Полтавської області. Діагноз на пастерельоз встановлювали комплексно, враховуючи епізоотологічні особливості, клінічні ознаки та патологоанатомічні зміни.

Діагностику захворювання здійснювали комплексно: з урахуванням епізоотологічних особливостей, клінічних ознак та результатів патологоанатомічного розтину. Визначальними у постановиі діагнозу були результати мікроскопічних та бактеріологічних досліджень. Для вивчення морфології мікроорганізмів мазки, з виділених культур, фарбували спиртововодним розчином метиленового синього. Вивчали чутливість виділеної мікрофлори до окремих антибактеріальних препаратів. Через 24 години інкубаиії на поживному середовищі виростали округлі, гладенькі, «воскові» колонії мікроорганізмів.

У мазках із колоній, щуо виросли на МПА були виявлені пастерели - характерні біполярні палички (рис.1). Після отримання чистої культури проводили визначення чутливості виділеного збудника до різних антибактеріальних речовин. Для цього використали диско-дифузійний метод. Після закінчення інкубації чашки Петрі розглядали та вимірювали у міліметрах зону затримки росту мікроорганізмів лінійкою.

Згідно до одержаних результатів, виділені культури пастерел виявили високу чутливість до тілозину. Даний антибактерійний засіб викликав зону затримки росту мікрофлори 14-21 мм; висока чутливість виділеної культури також була визначена до енрофлоксаџину (зона затримки росту - 16-24 мм) та гентаміцину (зона затримки росту - 18-24 мм) Помірно-стійкою культура виявилася до канаміцину та левоміцетину (зона затримки росту - 8-14 мм, відповідно). До решти препаратів виділена мікрофлора була резистентною, зона затримки росту мікрофлори коливалася від 0 до 4 мм.

Препарат Енроксіл 10\% розчин, на основі енрофлоксачину застосовували перорально з питною водою у розрахунку 5 мл препарату на 10 літрів води протягом трьох днів. У період лікування птиия отримувала лише воду, що містить препарат. Високу чутливість виділеної мікрофлори до низки антибактерійних засобів та високу ефективність лікувальних заходів можна пояснити вчасним зверненням власника зоопарку по допомогу зі встановлення діагнозу.
\end{abstract}

Ключові слова: гуси, пастерельоз, діагностика, заходи боротьби.

\section{Диагностика и мероприятия по ликвидации пастерелеза гусей в частном зоопарке Полтавской области}

\author{
Е.А. Передера, И.В. Лавриненко, И.А. Жерносик \\ ua151@ukr.net
}

Полтавская государственная аграрная академия,

ул. Сковороды, 1/3, г. Полтава, 36003, Украина

В статье приведены результаты исследования вспьшки пастереллеза гусей в частном зоопарке Полтавской области. Диагностику заболевания осуществляли комплексно: с учетом эпизоотологических особенностей, клинических признаков и результатов патологоанатомического вскрытия. Определяющими в постановке диагноза были результаты микроскопических и бактериологических исследований. Для изучения морфологии микроорганизмов мазки, из выделенных культур, краси-

Citation:

Peredera, O.O., Lavrinenko, I.V., Zhernosik, I.A. (2016). The diagnosis and elimination of pasterelosis geese in the privat zoo sn the Poltava region. Scientific Messenger LNUVMBT named after S.Z. Gzhytskyj, 18, 2(66), 152-156. 
ли спиртово-водным раствором метиленового синего. Изучали чувствительность выделенной микрофлоры к отдельньлм антибактериальных препаратов. Через 24 часа инкубации на питательной среде вырастали округлье, гладкие, «восковые» колонии микроорганизмов.

В мазках из колоний, выросших на МПА были обнаружены пастереллы - характерные биполярные палочки. После получения чистой культуры проводили определение чувствительности выделенного возбудителя к различныл антибактериальным вещееств. Для этого использовали диско-диффузионный метод. После окончания инкубации чашки Петри рассматривали и измеряли в миллиметрах зону задержки роста микроорганизмов линейкой.

Согласно полученным результатам, выделенные культуры пастерел обнаружили высокую чувствительность к тилозину. Данный препарат вызвал зону задержки роста микрофлоры 14-21 мм; высокая чувствительность выделенной культуры также была определена к энрофлоксацину (зона задержки роста - 16-24 мм) и гентамицину (зона задержки роста 18-24 мм) Умеренно-устойчивой культура оказалась к канамицину и левомицетина (зона задержки роста - 8-14 мм, соответственно). К другим препаратам выделенная микрофлора была резистентной, зона задержки роста микрофлоры колебалась от 0 до 4 мм. Препарат Енроксил 10\% раствор на основе энрофлоксацина применяли перорально с питьевой водой в расчете 5 мл препарата на 10 литров воды в течение трех дней. В период лечения птица получала только воду, содержашую препарат. Высокую чувствительность выделенной микрофлоры к ряду антибактериальных средств и высокую эффективность лечебных мероприятий можно объяснить своевременным обрашением владельца зоопарка за помощъью по установке диагноза.

Ключевые слова: гуси, пастерелез, диагностика, мероприятия по ликвидации.

\title{
The diagnosis and elimination of pasterelosis geese in the privat zoo sn the Poltava region
}

\author{
O.O. Peredera, I.V. Lavrinenko, I.A. Zhernosik \\ ua151@ukr.net \\ Poltava State Agrarian Academy, \\ Skovorody Str., 1/3, Poltava, 36003,Ukraine
}

\begin{abstract}
The results of the study geese pasteurellosis outbreaks in private zoo in the Poltava region. Diagnosis for pasteurellosis set comprehensively, taking into account epizootological features, clinical signs and pathological changes.

The diagnosis was carried out comprehensively, taking into account the characteristics of epizootic, clinical signs and postmortem autopsy results. In determining the diagnosis were the results of microscopic and bacteriological research. To study the morphology of microorganisms strokes, the selected cultures were stained with alcoholic-aqueous methylene blue. We studied the sensitivity of selected microorganisms to certain antibiotics. After 24 hours of incubation in nutrient medium grew rounded, smooth, «wax» colonies of microorganisms.

In smears of colonies that grew were found to IPA Pasteurella - typical bipolar coli. After obtaining a pure culture was carried determine the sensitivity of the selected pathogen to various antibacterial agents. For this we used disco-diffusion method. After the incubation, the Petri dish looked and measured in millimeters zone delay line growth of microorganisms.

According to the results obtained, isolated Pasteurella culture revealed high sensitivity to tilozyn. This antibacterial agent caused stunted growth zone microflora 14-21 mm; High sensitivity also highlighted the culture was determined to enrofloxacin (zone of stunted growth - 16-24 mm) and gentamicin (zone of stunted growth-18-24 mm) Moderately resistant culture was to kanamycin and chloramphenicol (zone growth retardation - 8-14 $\mathrm{mm}$ in accordance). To the rest of the drugs was highlighted microflora resistant, zone microflora growth delay ranged from 0 to $4 \mathrm{~mm}$.

The drug Enroksil 10\% solution, based on enrofloxacin used orally in drinking water at the rate of $5 \mathrm{ml}$ per 10 liters of water for three days. During treatment birds received only water containing the drug. The high sensitivity of microflora selected a number of antibacterial drugs and high efficiency of therapeutic measures can be explained by timely treatment zoo owner for help with diagnosis.
\end{abstract}

Key words: geese, pasteurellosis, clinical signs, pathological changes.

\section{Вступ}

В останні роки під впливом напруженої екологічної ситуації, еволюції світу мікроорганізмів, масової вакцинації тварин, безконтрольного та надмірного використання антибіотиків, хіміопрепаратів та інших факторів, що спричиняють зміни біоценозів, загрозливо змінився не лише список інфекційних захворювань, але і їх етіологічна структура, роль різних видів і сероваріантів мікроорганізмів у виникненні та розвитку інфекційних хвороб. У результаті відбувається зміна перебігу епізоотичного процесу, його циклічності, тривалості клінічного перебігу хвороби та її симптоматики, яка стає менш вираженою або набуває нових обрисів (Kovaljov et al., 1999; Zeljukina, 2008). У птахівництві серйозну небезпеку становлять інфек- ційні хвороби, поширенню яких сприяє значна концентрація поголів'я птиці на обмеженій площі, внутрішні та міжгосподарські зв'язки, порушення нормативних положень 3 вирощування птиці. Одним із захворювань, що наносить птахівництву України значні економічні збитки, є пастерельоз (German, 2002; Slugun, 2003).

Мета роботи - розробка ефективних заходів щодо ліквідації спалаху пастерельозу в умовах приватного зоопарку Полтавської області.

\section{Матеріал і методи досліджень}

Діагностику захворювання здійснювали комплексно: 3 урахуванням епізоотологічних особливостей, клінічних ознак та результатів патологоанатомічного 
розтину. Визначальними у постановці діагнозу були результати мікроскопічних та бактеріологічних досліджень (Pavlenko et al., 1995; Stegnij, 2009). Для вивчення морфології мікроорганізмів мазки, з виділених культур, фарбували спиртово-водним розчином метиленового синього. Вивчали чутливість виділеної мікрофлори до окремих антибактеріальних препаратів: амоксіцилін (20 мкг), доксіциклін (30 мкг), гентаміцин (120 мкг), тілозин (15 мкг), цефазолін (30 мкг), енрофлоксацин (5 мкг), тетрациклін (30 мкг) та бензилпеніцилін (10 ОД), левоміцетин (20 мкг) методом дифузії в агар із застосуванням дисків виробництва науково-дослідного центру фармакотерапії (СанктПетербург, Росія).

Для мікробіологічних досліджень стерильними інструментами відбирали кров із серця, шматочки печінки, легень, лімфатичних вузлів та проводили посіви на МПА. Після цього чашки Петрі ставили у термостат при температурі $37,5{ }^{\circ} \mathrm{C}$ i вели спостереження. Через 24 години на поживному середовищі виростали округлі, гладенькі, «воскові» колонії мікроорганізмів.

У мазках із колоній, що виросли на МПА були виявлені пастерели - характерні біполярні палички (рис.1). Після отримання чистої культури проводили визначення чутливості виділеного збудника до різних антибактеріальних речовин. Для цього використали диско-дифузійний метод.

Чашки Петрі діаметром 10 см поміщали на горизонтальну поверхню та заливали 30 мл розплавленого м'ясо-пептонного агару. Залишали при кімнатній температурі для застигання агару. Суспензію мікроорганізмів готували із 18 годинної агарової культури збудника. На поверхню агару вносили 1-2 мл суспен-
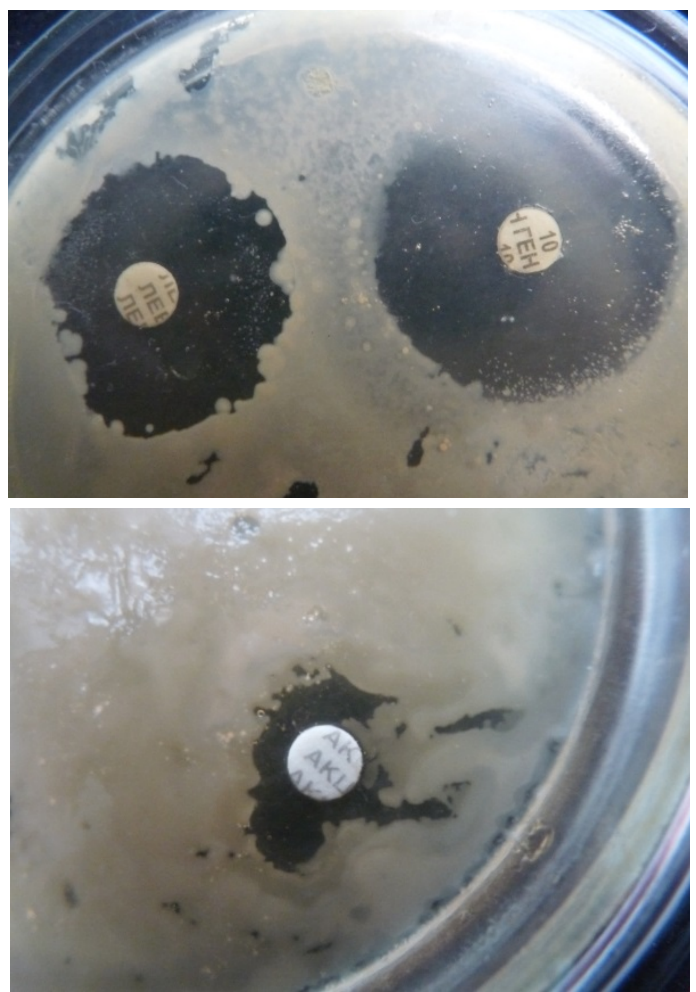

Рис. 2-5. Зони затримки росту культури пастерел за різних дисків 3 антибактерійними речовинами
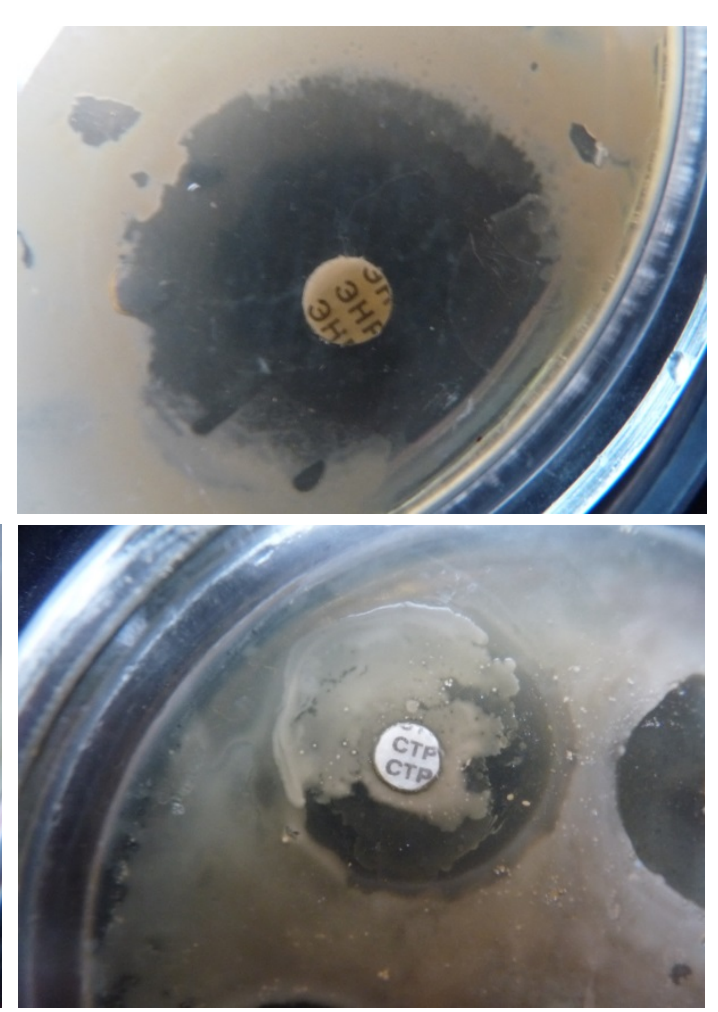

зії, рівномірно розподіляючи іiі на поверхні агару. Через 15 хв після внесення суспензії мікроорганізмів на поверхню поживного середовища за допомогою стерильного пінцета наносили диски з антибіотиками (4-5 на одну чашку Петрі). Диски акуратно притискали пінцетом до поверхні агару. Після цього чашки поміщали в термостат догори дном та інкубували 18 годин при $37^{\circ} \mathrm{C}$.

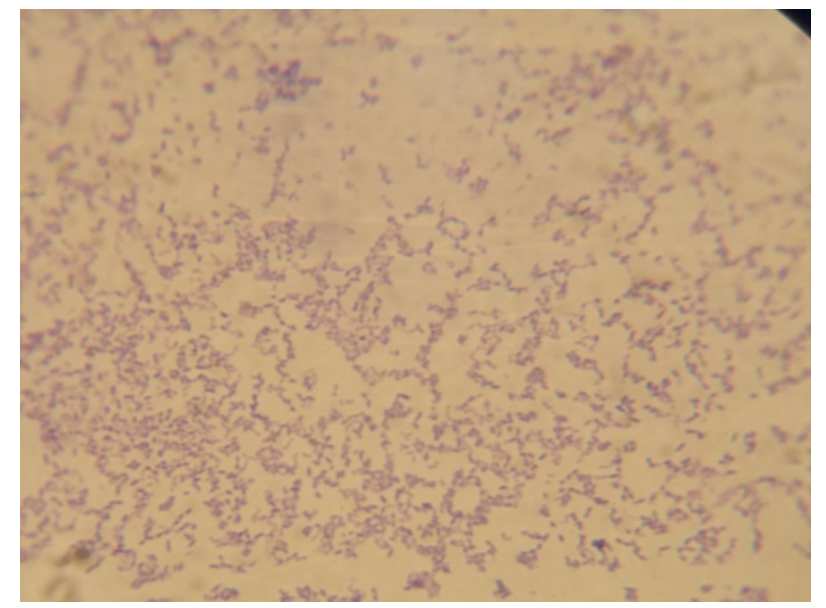

\section{Рис.1. Пастерели, виділені з печінки за гострого перебігу пастерельозу гусей}

Після закінчення інкубації чашки Петрі розглядали та вимірювали у міліметрах зону затримки росту мікроорганізмів лінійкою (рис. 2-5). 


\section{Результати та їх обговорення}

Результати оцінки визначення чутливості виділеної мікрофлори до окремих антибіотиків наведено в таблиці 1. Згідно до одержаних результатів, виділені культури пастерел виявили високу чутливість до тілозину. Даний антибактерійний засіб викликав зону затримки росту мікрофлори 14-21 мм; висока чутливість виділеної культури також була визначена до енрофлоксацину (зона затримки росту - 16-24 мм) та гентаміцину (зона затримки росту - 18-24 мм) Помірно-стійкою культура виявилася до канаміцину та левоміцетину (зона затримки росту - 8-14 мм, відповідно). До решти препаратів виділена мікрофлора була резистентною, зона затримки росту мікрофлори коливалася від 0 до 4 мм.
Гусей які знаходилися в неблагополучному господарстві ізолювали в окремому приміщенні. Оскільки виділена культура мікроорганізмів була чутлива до декількох антибактерійних засобів, для лікування було обрано препарат Енроксіл 10\% розчин, на основі енрофлоксацину. Діюча речовина препарату - фторхінолон (енрофлоксацин) має протимікробну дію відносно грампозитивних і грамнегативних мікроорганізмів, включаючи штами Escherichia spp., Salmonella spp., Pasteurella spp., Staphylococcus spp., Klebsiella spp., Pseudomonas spp., Bordetella spp., Campylobacter spp ., Corynebacterium spp., Proteus spp., Mycoplasma spp. Haemophilus spp.

Чутливість виділеної мікрофлори до окремих антибіотиків

\begin{tabular}{|c|c|c|}
\hline Назва препарату & $\begin{array}{c}\text { Зона затримки росту мікрофло- } \\
\text { ри, мм }\end{array}$ & Категорії чутливості \\
\hline Амоксіцилін & $0-4$ & Резистентний \\
\hline Стрептоміцин & $0-4$ & Резистентний \\
\hline Поліміксин & - & Резистентний \\
\hline Тілозин & $14-21$ & Чутливий \\
\hline Енрофлоксацин & $16-24$ & Чутливий \\
\hline Тетрациклін & - & Резистентний \\
\hline Гентаміцин & $18-24$ & Чутливий \\
\hline Цефазолін & $2-4$ & Резистентний \\
\hline Левоміцетин & $5-14$ & Помірно-стійкий \\
\hline Канаміцин & $8-13$ & Помірно-стійкий \\
\hline
\end{tabular}
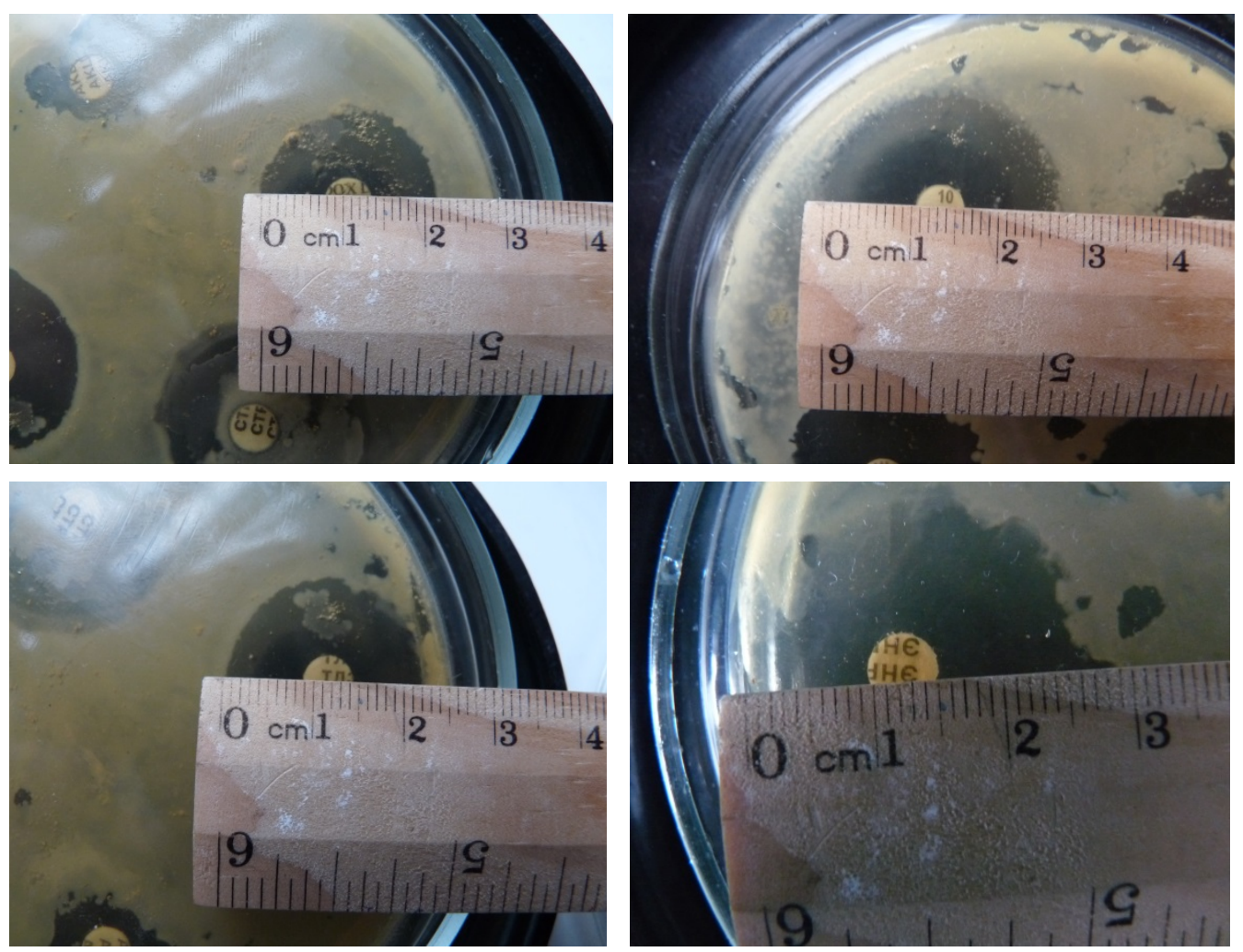

Рис. 6-9. Визначення чутливості виділеної культури збудника до антибактеріальних засобів 
Механізм дії препарату заснований на інгібіції активності ферменту гірази, що бере участь в процесі реплікації спіралі ДНК в ядрі бактеріальної клітини. Після перорального застосування енрофлоксацин добре всмоктується 3 шлунково-кишкового тракту i проникає в усі органи і тканини організму. Максимальна концентрація енрофлоксацину в плазмі крові досягається через 1,5 - 2 години після перорального застосування і продовжується протягом шести годин. Терапевтична дія 24 години. Виводиться в основному в незміненому вигляді 3 сечею і жовчю. За ступенем впливу на організм теплокровних тварин препарат належить до безпечних речовин і в рекомендованих дозах не чинить місцевоподразнюючої, резорбтивнотоксичного, алергізуючої та сенсибілізуючої дії.

Лікарський засіб застосовували птиці перорально 3 питною водою у розрахунку 5 мл препарату на 10 літрів води протягом трьох днів. У період лікування птиця отримувала тільки воду, що містить препарат.

Покращення клінічного стану хворої птиці було відмічено на другу добу після початку лікування: птиця стала реагувати на зовнішні подразники, з'явився апетит.

\section{Висновки}

Діагноз на пастерельоз гусей встановлювали комплексно, враховуючи епізоотологічні особливості, клінічні ознаки та патологоанатомічні зміни. Було виділено чисту культуру збудника пастерельозу та визначено іiі чутливість до ряду антибактерійних засобів. Висока чутливість мікрофлори була встановлена до тілозину, енрофлоксацину та гентаміцину. Тому у даному господарстві для лікування пастерельозу гусей використовували препарат Енроксіл $10 \%$ роз- чин, на основі енрофлоксацину. Його застосовували птиці перорально 3 питною водою у розрахунку 5 мл препарату на 10 літрів води протягом трьох днів. У період лікування птиця отримувала лише воду, що містить препарат. Високу чутливість виділеної мікрофлори до низки антибактерійних засобів та високу ефективність лікувальних заходів можна пояснити вчасним зверненням власника зоопарку по допомогу зі встановленням діагнозу. Власник не застосовував лікувальні засоби для хворої птиці навмання, а строго дотримувався наданих йому рекомендацій.

\section{Бібліографічні посилання}

Zeljukina, Ja.S. (2008). Rol' P. multocida v smeshannyh infekcijah ptic. Zb. nauk. prac'. Lugan. nac. agrar. un-tu. - Lugans'k. 92, 70 - 73 (in Russian).

Kovaljov, V.L., Zabolotnjaja, V.P., Sosnickij, A.I. (1999). Ustojchivost' paterell k antibiotikam. Sbornik materialov: mezhdunar. nauch.-prakt. konf., Minsk, 87 (in Russian).

Slugun, V.S. (2003). Pasterellez. Veterinarija. 7, 3 - 7 (in Russian).

German, V.V. (2002). Pasterel'oz. Dovidnyk z hvorob ptyci. 62-64 (in Ukrainian).

Pavlenko, M.S., Manchenko, V.M., Obrazhej, A.F., Zavirjuha, A.I. (1995). Nastanova z laboratornoi' diagnostyky pasterel'oziv tvaryn ta ptahiv. (in Ukrainian).

Stegnij, B.T. (2009). Metodychni rekomendacii' z diagnostyky, profilaktyky ta zahodiv borot'by $\mathrm{z}$ pasterel'ozom (holeroju) ptyci. Dnipropetrovs'k, 4-39 (in Ukrainian).

Стаття надійшла до редакциї 22.08.2016 